Georgetown University Law Center

Scholarship @ GEORGETOWN LAW

2021

\title{
Potential Competition and Antitrust Analysis: Monopoly Profits Exceed Duopoly Profits
}

Steven C. Salop

Georgetown University Law Center, salop@law.georgetown.edu

This paper can be downloaded free of charge from:

https://scholarship.law.georgetown.edu/facpub/2380

https://ssrn.com/abstract=3839631

This open-access article is brought to you by the Georgetown Law Library. Posted with permission of the author. Follow this and additional works at: https://scholarship.law.georgetown.edu/facpub

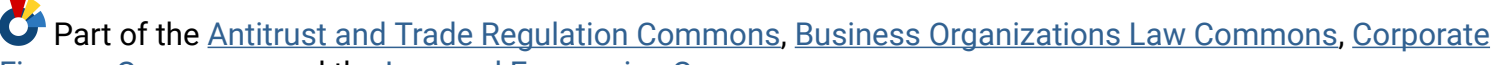
Finance Commons, and the Law and Economics Commons 


\section{Potential Competition and Antitrust Analysis: \\ Monopoly Profits Exceed Duopoly Profits \\ Steven C. Salop*}

\section{Table of Contents}

I. INTRODUCTION............................................................................................................................

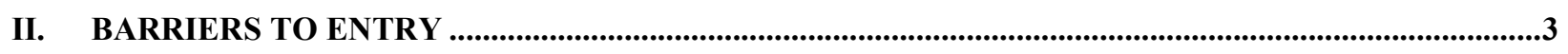

Figure 1: Post-Entry Competition as an Entry Barrier .................................................................................5

Figure 2: Comparing Minimum Viable Scale (MVS) and Minimum Efficient Scale (MES) .............................5

III. ACQUISITIONS OF POTENTIAL OF NASCENT COMPETITORS ..........................................................6

A. Horizontal, Vertical and Complementary Product Potential Competitors ……............................

B. LEGAL STANDARDS FOR ACQUISITIONS OF POTENTIAL COMPETITORS ..............................................................

C. THE RATIONALE FOR AN ANTICOMPETITIVE PRESUMPTION ...........................................................................12

Table 1: The Inherent Bidding Advantage of a Dominant Firm ……..................................................... 15

IV. ANTICOMPETITIVE CONDUCT TO EXCLUDE NASCENT OR POTENTIAL COMPETITORS...16

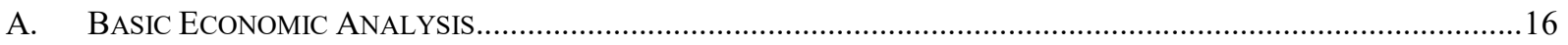

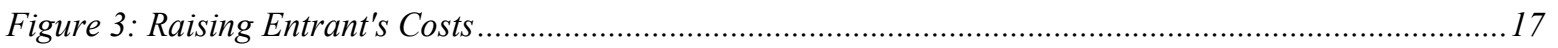

B. The COMPETITIVE BENEFITS OF EVEN LeSS-EFFICIENT COMPETITORS ……............................................. 18

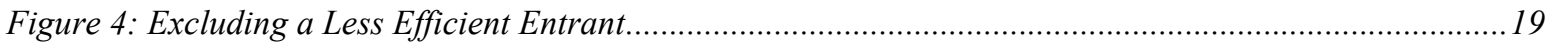

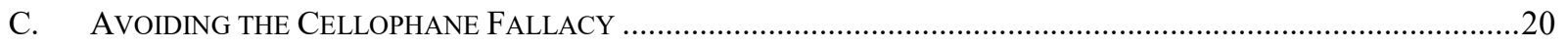

D. COMPETITIVE BIDDING FOR CRITICAL DISTRIBUTION SERVICES OR OTHER ESSENTIAL INPUTS .....................21

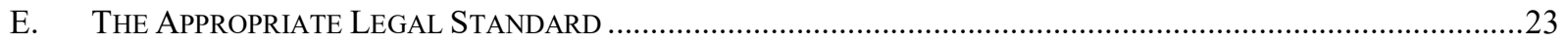

V. EXCLUSIONARY AGREEMENTS BETWEEN INCUMBENTS AND POTENTIAL OR NASCENT

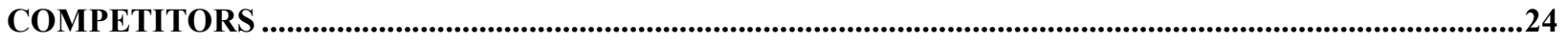

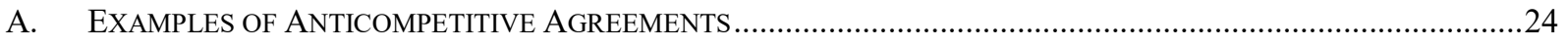

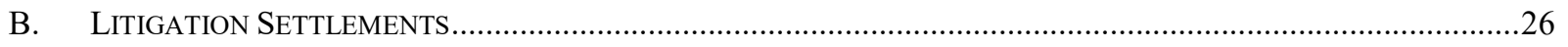

VI. CONCLUSIONS ............................................................................................................................................27 


\section{INTRODUCTION}

1. In preparation for the OECD panel in June 2021, this short note examines and remarks on several relevant antitrust issues involving analysis of potential competition. ${ }^{1}$ I do not think that any of the analysis in the article is new. I expect that all the points have been made elsewhere by others and myself. But, it is still useful to collect them together in a unified fashion to show how they are related.

2. In this regard, all the analysis and conclusions flow from the overarching (and obvious) points that exclusionary conduct and agreements that maintain monopoly power very often harm consumers, and that monopoly profits typically exceed the total market profits earned by the dominant firm and the entrant combined in the duopoly market that occurs if there is successful entry. This is not inevitably the case. ${ }^{2}$ However, it is a working assumption for most market situations.

3. The fact that a monopolist's profits normally exceed a market's total duopoly profits explains why a dominant firm has the incentive to destroy nascent competitors and deter potential competitors. By doing so, the dominant firm can preserve its monopoly power and monopoly profits. This observation similarly explains the incentive to acquire nascent or potential competitors or reach agreements with them that reduce or eliminate that competition.

4. Three deeper economic points involve the incentives of the dominant firm and the entrant that follow from the fact that monopoly profits normally exceed their combined duopoly profits. First, the lower combined profits explain why the dominant firm would have the incentive to pay a higher acquisition price for a nascent or potential competitor than would other smaller acquirers. Second, it explains why the dominant firm and the entrant would have the mutual incentives to make an agreement by which the entrant delays its entry or withdraws entirely. Third, the lower combined profits explain why the dominant firm would have the incentive and ability to outbid a nascent competitor for access to distribution services or other inputs that are essential to the viability of the nascent competitor. These incentives and resulting market impact have been well understood in economics for decades. ${ }^{3}$

\footnotetext{
*Professor of Economics \& Law, Georgetown University Law Center; Senior Consultant, Charles River Associates (Washington, DC). This article has been prepared for the OECD's Roundtable on Potential Competition in June 2021. I would like to thank Jonathan Baker, Florian Ederer, John Newman, Tomasso Valletti and Logan Billman for helpful comments. The opinions in this article are my own and may not be shared by my colleagues or consulting clients. All errors are my own.

${ }^{1}$ I have numbered the paragraphs for easy reference.

${ }^{2}$ Monopoly profits are not always higher. The entrant may have much lower costs or a better or highly differentiated product. But higher monopoly profits are more usually the case.

${ }^{3}$ Richard J. Gilbert and David M. G. Newbery, Preemptive Patenting and the Persistence of Monopoly, 72 AMERICAN ECON. REV. 514 (1982). ${ }^{4}$ U.S. Dep't of Justice \& Fed. Trade Comm'n, Horizontal Merger Guidelines
} 
5. This analysis also explains why it is important for competition policy to protect effective competition from nascent and potential competitors. Those competitors often are the leading edge which undermines the monopoly power of dominant firms. And because monopoly profits exceed competitive profits, the deck is stacked against them. The dominant firm's incentive to spend is greater than the entrant's because the dominant firm is spending to protect its monopoly profits while the entrant is spending to achieve the lesser, competitive duopoly profits.

6. The importance of nascent and potential competition and the asymmetry of the stakes involved suggests that competition law should place an anticompetitive presumption on alleged exclusionary conduct and acquisitions by dominant firms. Likewise, enforcement agencies should closely monitor their agreements, including litigation settlements, to determine whether the agreements are serving to eliminate competition and preserve monopoly power.

7. The remainder of this note is organized as follows. Section II discusses barriers to entry, including the fact that the anticipation of post-entry competition is itself a barrier to entry. Section III discusses some issues related to acquisitions of nascent or potential competitors. Section IV discusses some issues related to exclusionary agreements between dominant incumbents and nascent or potential competitors. Section V discusses anticompetitive exclusionary conduct that targets nascent or potential competitors. Section VI concludes.

\section{BARRIERS TO ENTRY}

8. The OECD organizers requested discussion of the definition of barriers to entry. For the purposes of antitrust analysis, entry barriers are technological and market impediments that would prevent new entrants from deterring or reversing the profitable exercise of anticompetitive conduct alleged in a particular matter. I use this general definition because the relevant impediments may depend on the type of matter. For example, if the matter involves a proposed merger in a competitive market, the relevant issue is whether actual or threatened entry would deter or prevent price increases above the competitive price. By contrast, if the matter involves a dominant firm engaging in exclusionary conduct to destroy its only small competitor that was well-situated to cause prices to decline to a more competitive level, then the relevant issue is whether actual or threatened entry by others would effectively replace the competitive force of the excluded competitor.

9. The U.S. Horizontal Merger Guidelines summarize the analysis of entry by stating that entry will be considered "easy" if entry would be timely, likely, and sufficient. ${ }^{4}$ However, these

$\S \S 9-9.3$ (2010) (hereinafter US HMGs), available at https://www.ftc.gov/system/files/documents/public_statements/804291/100819hmg.pdf.

${ }^{4}$ U.S. Dep’t of Justice \& Fed. Trade Comm’n, Horizontal Merger Guidelines $\S 9$-9.3 (2010) (hereinafter US $H M G s$ ), available at https://www.ftc.gov/system/files/documents/public_statements/804291/100819hmg.pdf. 
three terms - particularly the circumstances under which entry is "likely" - involve a deeper economic analysis, which I will summarize here.

10. Barriers to entry can arise from technological, resource or market factors that lead potential entrants to have costs that would make it impossible or more difficult to enter. Similarly, lack of a reputation or track record also can weaken an entrant's ability to achieve viability or constrain the pricing of the defendant(s). Patents, other intellectual property or government regulations also may impede entry that would constrain the profitability of the conduct.

11. If entry takes a long time, then the fear of entry may not provide a substantial constraint on conduct. The firm can enjoy higher prices and profits until the entry occurs. Even if a strong entrant into the 12-year-old scotch market begins the entry process immediately upon announcement of the merger of its rivals, it will not be able to constrain prices for a long time. The dominant firm also could preempt the entrant by reducing price right before the entry occurs.

12. If entry involves sunk costs and economies of scale, the fear of post-entry competition can weaken or eliminate the likelihood of entry. For example, suppose there is a merger to monopoly and the monopolist raises price up to the monopoly level. Suppose that the potential entrant can sell a fungible product at the same marginal and fixed costs as the monopolist. In this situation, if the entrant must obtain a substantial scale to achieve breakeven profits (i.e., a substantial minimum viable scale), its entry may set off post-entry price competition. ${ }^{5}$ As price falls, the entrant must grow further to achieve the higher breakeven scale at the lower price, which can intensify the price war and create a "death spiral" for the entrant. In the end, the market equilibrium price might involve the entrant having negative profits and losing its sunk costs. If this is the case, a foresighted entrant would choose not to enter, and the fear of entry would not constrain the post-merger pricing of the merged firm. In this very real sense, post-entry price competition creates a barrier to entry.

13. This dynamic process and the resulting negative profit outcome for the entrant is illustrated in Figure 1. The analysis demonstrates that entry is less likely to occur when minimum viable scale is high and when sunk costs are significant. It also is noteworthy that this barrier to entry does not require the entrant to be less efficient than the dominant firm. The barrier to entry arises from a different asymmetry -- the entrant has not sunk costs into the market, whereas the dominant firm already has sunk its costs. The fear of loss-producing post-entry competition will deters the entrant that has not yet sunk costs. But it will not cause the

\footnotetext{
${ }^{5}$ See Steven C. Salop, Measuring Ease of Entry. 31 ANTIRUST BULLETIN 551 (1986), for an early analysis focusing on the role and measurement of minimum viable scale (MVS). The 1992 Merger Guidelines had the further insight that MVS should be evaluated at the pre-merger price, not at a SSNIP above that price. See U.S. Dep't of Justice \& Fed. Trade Comm'n, Horizontal Merger Guidelines §3 (1992), available at https://www.justice.gov/archives/atr/1992-merger-guidelines.
} 
incumbent monopolist to exit. To the contrary, it will be able to continue to enjoy its monopoly profits without fear of entry.

\section{Figure 1: Post-Entry Competition as an Entry Barrier}

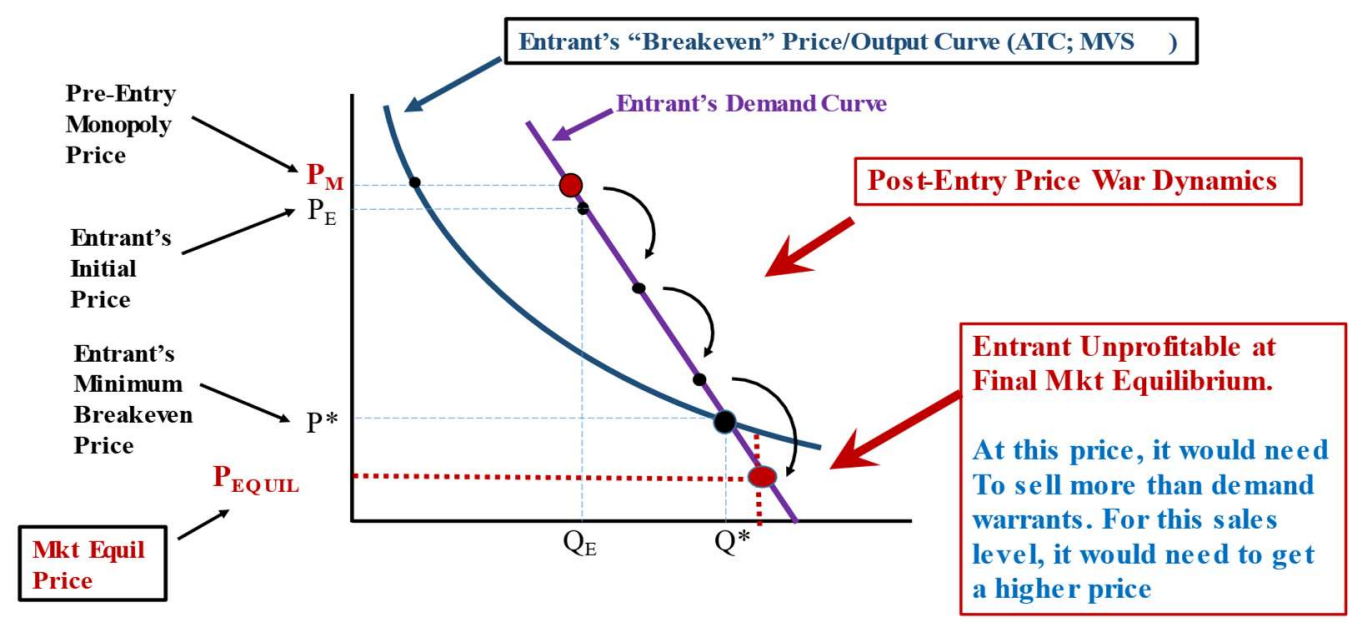

14. Note also that minimum viable scale is different from minimum efficient scale, as illustrated in Figure 2 below.

\section{Figure 2: Comparing Minimum Viable Scale (MVS) and Minimum Efficient Scale (MES)}

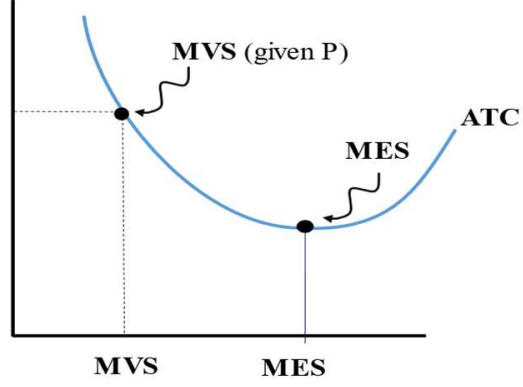

Some commentators use these terms

interchangeably but they actually are very

different.

MVS is a market-based concept. the entrant's

breakeven output level, which depends on the

market price.

MES is a purely technology -based concept. It is the output level at which average total costs

(ATC) are minimized.

In a "perfectly competitive" market, the long -run

price will equilibrate at the price corresponding

to the MES output. In such a market,

MES=MVS. But, this is not relevant for the

oligopoly markets most relevant for antitrust. 
15. If there is no death spiral and the entry succeeds, this same analysis also shows that postentry price (or other) competition is the fundamental reason why monopoly profits exceed the combined profits of the duopolists. It is this reduction in combined profits that forms the anticompetitive motive for acquisitions of potential entrants, exclusionary agreements, and exclusionary conduct to weaken or destroy the entrants or deter their attempts to enter discussed in this article.

16. Barriers to entry also can arise from the anticompetitive conduct of the firms in the market, in particular, the defendant(s) in a particular case. If a dominant firm engages in exclusionary conduct, that conduct itself can create barriers to entry. For example, suppose that the dominant firm (or a group of firms that forms a joint venture) acquires all the supplies of a critical (or essential) input. In that case, a potential entrant may have to bear much higher or prohibitive costs or may even be unable to obtain the input at any price. Exclusionary conduct also can create a reputation for predation for the dominant firm that will deter entry by others. To take an extreme example, suppose that the factory of a new entrant is destroyed and there are unconfirmed rumors that the dominant firm was the source of the arson.

17. The fact that entry by an efficient entrant can occur does not mean that it would be sufficient to prevent the exercise of market power. For example, if there were only a single entrant with limited capacity (or a group of potential entrants that collectively had limited capacity), then its entry need not force the dominant firm to reduce its price. The dominant firm might simply accommodate the limited entry rather than cut its price to maintain a higher market share. For this reason, the analysis of entry barriers must also account for the possibility that the entrant could choose to limit its capacity, precisely to incentivize the dominant firm to accommodate its entry. ${ }^{6}$

\section{III.ACQUiSITIONS OF POTENTIAL OF NASCENT COMPETITORS}

18. Acquisitions of potential or nascent competitors by a dominant firm raise inherent anticompetitive concerns. By eliminating the procompetitive impact of the entry, an acquisition can allow the dominant firm to continue to exercise monopoly power and earn monopoly profits. The dominant firm also can neutralize the potential innovation competition that the entrant would provide. ${ }^{7}$ In this section, I will discuss some issues related to competition policy for such acquisitions. Section A explains how the acquisition

\footnotetext{
${ }^{6}$ See, e.g., Avner Shaked \& John Sutton, Relaxing Price Competition Through Product Differentiation, 49 REV. ECON. STUD. 3 (1982); Judith R. Gelman \& Steven C. Salop, Judo Economics: Capacity Limitation and Coupon Competition, 14 Bell J. ECON. 315 (1983); Lacy A. Thomas, Incumbent Firms' Response to Entry: Price, Advertising, and New Product Introduction. 17 INT'L J. IND. ORG. 527 (1999); Xavier Wauthy \& Nicolas Boccard, Entry under Capacity Limitation and Vertical Differentiation: Return of the Judo Economics (November 10, 2008), available at https://ssrn.com/abstract $=1299009$.

${ }^{7}$ See Colleen Cunningham, Florian Ederer, and Song Ma, Killer Acquisitions, 129 J. PoL. ECON. 143 (2020); Scott Hemphill and Tim Wu, Nascent Competitors, 168 U. PA. L.R. 1879 (2021).
} 
of a vertically adjacent or complementary producer also can raise potential competitive concerns. Section B proposes a strong anticompetitive presumption should apply to such mergers and explains the rationale. Section $\mathrm{C}$ explains the potential pitfalls that can arise from the infamous Cellophane Fallacy.

\section{A. Horizontal, Vertical and Complementary Product Potential Competitors}

19. Consideration of potential competitor acquisitions normally centers on "horizontal" acquisitions, that is, a situation where an established (often leading) firm acquires a firm that is a nascent or potential participant (i.e., a seller or buyer) in the same market. However, potential competitor acquisitions also can raise competitive concerns when the acquired firm is a participant in a vertically adjacent or complementary product market. These so-called non-horizontal acquisitions can raise competitive concerns because the acquired firms may become a direct competitor to the acquiring firm at some point in the future. For example, while YouTube may have been complementary to Google's search engine at the time of the acquisition, it might have grown into an advertising competitor in the future. Similarly, while Instagram might have provided an efficient photo-sharing technology that Facebook could utilize, it might have grown into a social media competitor absent the acquisition.

20. Alternatively, the acquired firm may be an "indirect" competitor of the acquiring firm by virtue of it providing additional competitive support to rivals of the acquiring firm. ${ }^{8} \mathrm{~A}$ new entrant into the input market can lead to lower input prices and greater competition in the output market, which might decrease the market power of a dominant downstream competitor that has a cost advantage. If the downstream dominant firm instead acquires the new input entrant and has it charge higher input prices or totally foreclose downstream rivals from access to the entrant's product, the dominant firm may be able better to maintain its monopoly power. Similarly, producers of complementary products have the incentive to take actions that increase competition in the adjacent market. Thus, the dominant firm would have the incentive to acquire and control a new entrant into the complementary product market in order to prevent the entrant from supporting its own competitors.

21. These competitive concerns from acquisitions of nascent or potential vertically adjacent or complementary product competitors suggest that the very permissive safe harbors in the EU's Non-Horizontal Merger Guidelines should be deleted. ${ }^{9}$ Indeed, my own view is that such safe harbors also are inappropriate for evaluating acquisitions of established firms in vertically adjacent or complementary product mergers, except perhaps when both firms

8 See Serge Moresi \& Steven C. Salop, When Vertical is Horizontal: How Vertical Mergers Lead to Increases in "Effective Concentration. _ Rev. Ind. Org. _ (2021), available at

https://papers.ssrn.com/sol3/papers.cfm?abstract $\mathrm{id}=3761372$, for a formal economic analysis of this indirect competition.

${ }^{9}$ Guidelines on The Assessment of Non-Horizontal Mergers under The Council Regulation on The Control of Concentrations between Undertakings, 2008 O.J. (C 265) 6. 
compete in unconcentrated markets. ${ }^{10}$ A safe harbor certainly should not be applied if only one of the markets is unconcentrated. For example, suppose that the input market is concentrated but the output market is not. Input foreclosure that raises the cost of all or most of the competitors in an unconcentrated downstream market could cause substantial diversion to the merged firm's downstream affiliate, which would make the input foreclosure profitable and lead to higher downstream prices. ${ }^{11}$ The effects on coordination from eliminating an upstream maverick also do not require a concentrated downstream market, whereas upstream concentration makes it more likely that a maverick would constrain coordination in that market. Similarly, a disruptive buyer in an unconcentrated downstream market might constrain coordination in a concentrated upstream market, and its acquisition by an upstream firm could make that coordination more effective.

22. There are numerous examples of the relevance of this expanded domain of potential competitors. In the U.S. Microsoft case, for example, the government's preferred remedy was to divide Microsoft into an operating systems company (OSCo) and an applications company (AppsCo). ${ }^{12}$ The idea was that AppsCo would support -- if not sponsor -- entry into the operating system market. A beneficial side effect may have been that OSCo would have supported competitors of Microsoft Office, which also held a dominant position at the time.

23. The recently proposed acquisition of Farelogix by Sabre that was analyzed and prohibited by the UK CMA is another example. ${ }^{13}$ Farelogix was a nascent competitor in the sale of technology that airlines could use to disintermediate Sabre and other travel networks. By acquiring Farelogix, Sabre would eliminate that potential competition. In the U.S., the Department of Justice characterized Farelogix as a direct horizontal competitor of Sabre in the sale of booking services to travel agencies, rather than a seller in the vertically-related market for the technology. This characterization apparently confused the judge, who concluded that Sabre and Farelogix were not competitors in the relevant two-sided market,

\footnotetext{
10 Jonathan B. Baker, Nancy L. Rose, Steven C. Salop \& Fiona Scott Morton, Five Principles for Vertical Merger Enforcement, 33 ANTITRUST 12 (2019).

11 To illustrate, suppose that the upstream input market is a duopoly and the downstream output market is unconcentrated and comprised of ten firms, each with a market share of $10 \%$. If the vertical merger leads both upstream firms to raise prices significantly to the nine unintegrated competitors, their resulting cost increases could cause them to raise downstream prices, creating substantial customer diversion to the downstream affiliate of the merged firm and providing that affiliate with the power and incentive to raise its price (rather than simply increase its market share). See Jonathan B. Baker, Nancy L. Rose, Steven C. Salop \& Fiona Scott Morton, Recommendations and Comments on the Draft Vertical Merger Guidelines. (February 24, 2020) at 1-16, available at https://scholarship.law.georgetown.edu/facpub/2239/, for further examples, including ones that involve switching costs or product differentiation.

${ }^{12}$ United States v. Microsoft Corporation, 253 F.3d 34 (D.C. Cir. 2001).

${ }^{13}$ Competition \& Markets Authority, Anticipated acquisition by Sabre Corporation of Farelogix Inc., Final Report, (Sep. 2, 2019), available at Sabre / Farelogix final report (publishing.service.gov.uk).
} 
and refused to enjoin the merger. ${ }^{14}$ Of course, the CMA took a more sophisticated economic approach and refused to permit the merger.

\section{B. Legal Standards for Acquisitions of Potential Competitors}

24. Traditional antitrust treatment of acquisitions of potential or nascent competitors has properly been criticized as overly permissive. Under current U.S. law, for example, there is no anticompetitive presumption against the acquisition of a potential competitor. Instead, the enforcement agencies face a heightened burden of proof. ${ }^{15}$ Significantly, the enforcement agencies have litigated only one potential competition case since the $1980 \mathrm{~s} .{ }^{16}$ In that singular case, FTC v. Steris Corporation, the FTC failed in its case to block Steris' acquisition of Synergy. ${ }^{17}$

25. U.S. law distinguishes between actual and perceived potential competitors. ${ }^{18}$ An established firm may perceive that an outside firm is a potential threat at current prices or if the established firm raises its price. Either way, the perception may deter the established firm from raising price. The established firm may perceive an entrant threat whether or not the outside firm is likely to enter. That is, the outside firm may be a perceived potential entrant but not actual potential entrant. An actual potential entrant is one that likely will enter the market. ${ }^{19}$ The actual entrant may or may not deter price increases by the established firm. ${ }^{20}$ An established firm may have the incentive to acquire an actual potential entrant. An

\footnotetext{
${ }^{14}$ United States v. Sabre Corp., 452 F. Supp. 3d 97 (D. Del. 2020).

${ }^{15}$ Specifically, the Supreme Court required that an enforcement agency show, as necessary but insufficient "preconditions" to section 7 liability, that (1) the potential competitor had "feasible means" for entering the market at issue and (2) those means "offered a substantial likelihood" of "producing deconcentration of the market or other significant procompetitive effects." United States v. Marine Bancorporation, 418 U.S. 602, 633 (1974). The Supreme Court has not articulated what evidence is sufficient to discharge an enforcement agency's burden of proof under an actual competition theory. See Marine Bancorporation, 418 U.S. at 639 (disposing of the case because the Department of Justice's evidence failed to show the occurrence of the two preconditions). Lower courts tend to articulate proof of an actual potential competition theory as requiring evidence of (1) a concentrated market, (2) no other potential entrants exist other than the target (or acquirer), (3) probability of procompetitive entry and (4) procompetitive effects of independent entry. See Mercantile Texas Corp v. Board of Governors of the Federal Reserve System, 638 F.2d 1255 (5th Cir. 1981).

${ }^{16}$ The agencies have alleged the elimination of potential competition in complaints predicating settlements and abandonment. See, e.g., complaint at 4 -16b., In the matter of Mylan (F.T.C. Nov. 2, 2015) (C-4557).
}

${ }^{17}$ FTC v. Steris Corp., 133 F. Supp. 3d 962, 966 (N.D. Ohio 2015). According to the FTC, it was only necessary to show that the potential competitor "probably would have entered" the market absent the merger. $I d$.

${ }^{18}$ United States v. Marine Bancorporation, 418 U.S. 602, 624-25 (1974); United States. v Falstaff Brewing Corp, 410 U.S. 526 (1973); United States v. Phillips Petroleum Corp., 367 F. Supp. 1226, 1234; 1254-56 (C.D. Cal. 1973), aff'd mem. sub nom. Tidewater Oil Co. v. United States, 418 U.S. 906 (1974), reh'g denied, 419 U.S. 886 (1974); In re Brunswick Corp., 94 F.T.C. 1174, 1273 (1979), aff'd sub nom. Yamaha Motor Co. v. FTC, 657 F.2d 971 (8th Cir. 1981); In re Polypore Int'l, Inc., No. 9327, 2010 FTC LEXIS 97, at*72 n.41 (2010).

${ }^{19}$ The established firm may or may not perceive the existence of an actual entrant.

${ }^{20}$ For example, expecting entry to occur, the established firm may maximize profits by raising price for a short period, even if that harms its reputation. 
established firm also may have the incentive to acquire a perceived potential entrant, whether or not it turns out to be an actual potential entrant in reality. In this case, perception rules. Both actual and perceived potential entrants similarly may have incentives to acquire established firms. Whichever firm is the acquirer, profits will be higher if pre-merger or postmerger prices are no longer constrained after the acquisition.

26. To prove that a merger which eliminates a potential competitor violates $\S 7$, the enforcement agencies must advance one of two different theories of harm: actual potential competition and perceived potential competition. ${ }^{21}$ Actual potential competition harm occurs when a merger forecloses the acquiring firm's future de novo entry into the acquired firm's market. ${ }^{22}$ Perceived potential competition harm occurs when the threat of new entry by the acquiring firm induced competitors in the acquired firm's market to perform more competitively. ${ }^{23}$

27. Current U.S. legal standards set a high bar for both theories. To establish a $\S 7$ violation through an actual potential competition theory, the enforcement agencies must prove that:

(1) the relevant market is oligopolistic;

(2) absent the acquisition, the acquiring firm would have entered the market in the near future either de novo or through acquisition of a little company; and

(3) such entry by the acquiring firm carried a substantial likelihood of ultimately producing deconcentration of the market or other significant procompetitive effects. $^{24}$

28. Likewise, to prove that a perceived potential competition merger is unlawful, the enforcement agencies must prove that:

(1) the relevant market is "substantially concentrated;"

(2) the acquiring firm has the "characteristics, capabilities, and economic incentive to render it a perceived potential de novo entrant;" and

${ }^{21}$ See Tenneco, Inc. v. FTC, 689 F.2d 346, 521 (2d Cir. 1982) (citing Marine Bancorporation, 418 U.S. at 624-25).

22 See 5 P. Areeda \& H. Hovenkamp, Antitrust Law 91121 a (3d ed. 2009).

${ }^{23}$ Id. See also Ford Motor Co. v. United States, 405 U.S. 562, 667-68 (1972). In Ford, the Supreme Court affirmed a trial court's conclusion that Ford's acquisition of Autolite's spark plug business would illegally reduce competition because, in part, Ford's presence on the "edge" of the spark plug market was a "deterrent to current competitors." The Court concluded that Ford's acquisition of Autolite would eliminate Ford's "moderating influence." Id.

${ }^{24}$ Alberta Gas Chemicals, Ltd. v. E. I. Du Pont de Nemours \& Co., 826 F.2d 1235, 1255 (3rd Cir. 1987) (citing Tenneco, Inc. v. F.T.C., 689 F.2d 346, 352 (2d Cir. 1982)) (Becker, J., dissenting). The Supreme Court has not expressly identified the factual showing sufficient to prove a violation through an actual potential competition theory. See Marine Bancorporation, 418 U.S. at 633. Instead, the Court announced that any viable formulation of the theory requires, at minimum, proof that (1) the potential competitor had "feasible means" for entering the market at issue and (2) those means "offered a substantial likelihood" of "producing deconcentration of the market or other significant procompetitive effects." Id. (holding for defendants because the government failed to meet these minimum "preconditions"). This formulation of the necessary elements has emerged from the lower courts. See., e.g., Tenneco, 689 F.2d at 351. 
(3) the "acquiring firm's premerger presence on the fringe of the target market in fact tempered oligopolistic behavior on the part of existing participants in that market." 25

29. These legal standards place a very high burden on the agencies. First, the burden of showing that the acquired firm in an case is a likely entrant is weighty. For example, in its 1984 BAT decision, the FTC required "clear proof" that the entry would have occurred. Similarly, in Steris, the FTC alleged that Synergy was a likely potential entrant into the U.S. market for contract medical sterilization, a market which Steris led. The court rejected the claim, holding that the FTC did not show that Synergy "probably" would have entered the market absent the merger. Another heavy burden is the requirement that the agency prove the potential entry would result in deconcentration. This is especially the case in circuits which require deconcentration be "probable." 26

30. Second, even if the agency surpasses these evidentiary hurdles and establishes a prima facie $\S 7$ violation, it also must show that the independent entry likely would have significant procompetitive effects, relative to the acquisition. The agency must prove the merger has an anticompetitive effect (here, that level of competition without the merger exceeds the postmerger level) because there is no judicial anticompetitive presumption for potential competition mergers.

31. The agency might satisfy this burden with evidence of an anticompetitive motivation for the acquisition and/or evidence that the entry likely would have succeeded in increasing competition. The agency also could provide evidence of some emerging direct competition in the acquirer's primary market in markets vertically adjacent to the incumbent's primary market, along with a showing that this competition would be lost if the deal is permitted. ${ }^{27}$ The agency also would need to show that there were not a sufficient number of other potential entrants to replace the competitive constraint provided by the acquired entrant.

32. The agency's proof of anticompetitive effect also must be strong enough to defeat the parties' rebuttal evidence. For example, the parties might provide evidence that the acquired firm may not succeed if it enters independently. They also might provide evidence that nonpretextual, merger-specific efficiencies of combining the two companies would prevent competitive harm.

\footnotetext{
${ }^{25}$ Marine Bancorporation, 418 U.S. at 624-25; see also Tenneco, 689 F.2d at 355; United States v. Siemens Corp., 621 F.2d 499, 505 (2d Cir. 1980)

${ }^{26}$ Compare Yamaha Motor Co., 657 F.2d 971 (requiring that deconcentration would be probable) with Tenneco, 689 F.2d at 352 (requiring a "substantial likelihood") and Siemens Corp., 621 F.2d at 505 (same).

${ }^{27}$ See Hemphill and Wu, supra note 7 at 1902.
} 
33. Thus, the current legal standard sets a high bar. For acquisitions by dominant platforms, it is the view of myself and others that this bar is set far too high. Instead, the law should apply an anticompetitive presumption with a high rebuttal burden to such acquisitions of nascent of potential competitors. I turn next to the rationale for this presumption.

\section{The Rationale for an Anticompetitive Presumption}

34. Numerous commentators have suggested that the legal standard be made more intrusive and that the law adopt an anticompetitive presumption when the acquiring firm is dominant and an associated high rebuttal burden such as clear and convincing evidence that the merger would not reduce competition. ${ }^{28}$ Senator Klobuchar's recent proposed amendment to the U.S. antitrust laws similarly would mandate such an anticompetitive presumption and high rebuttal burden. ${ }^{29}$

35. As a general matter there is always a presumption, though it may be implicit and be "competitively neutral." 30 Because most mergers have not been consummated at the time of evaluation, the determination of the likely competitive effects is based on a prediction. This is also true of conventional horizonal mergers. But here, the prediction is harder because there are fewer market facts about target. As decision theory teaches, placing more weight on presumptions is appropriate where evidence is less reliable. ${ }^{31}$ That is the case here.

36. Applying an anticompetitive presumption with a high rebuttal burden would be particularly appropriate to apply to dominant platforms. The rationale for this presumption in wellgrounded in decision theory.

37. First, the appropriate assumption regarding the "but-for world" should not automatically be assumed to be a scenario where the entrant remains as a "standalone" firm. Instead, it generally is more appropriate to recognize that the entrant might be acquired by a different

\footnotetext{
${ }^{28}$ Various U.S. commentators have proposed anticompetitive presumptions for potential competition mergers or other exclusionary conduct. See, e.g., Jonathan B. Baker, Joseph Farrell, Andrew Gavil, Martin Gaynor, Michael Kades, Michael Katz, Gene Kimmelman, A. Douglas Melamed, Nancy L. Rose, Steven C. Salop, Fiona Scott Morton and Carl Shapiro, Joint Response to the House Judiciary Committee on the State of Antitrust Law and Implications for Protecting Competition in Digital Markets (2020), available at https://equitablegrowth.org/wpcontent /uploads/2020/04/Joint-Response-to-the-House-Judiciary-Committee-on-theState-ofAntitrust-Lawand-Implications-for-Protecting-Competition-in-Digital-Markets.pdf. Jonathan B. Baker, Nancy L. Rose, Steven C. Salop \& Fiona Scott Morton, Five Principles for Vertical Merger Enforcement Policy, 33 ANTITRUST 12, (2019), available at https://www.americanbar.org/digital-assetabstract.html/content/dam/aba/publishing/antitrust_magazine/atmag-summer2019/smmr19-bakerc.pdf; Carl Shapiro, Antitrust: What Went Wrong and How to Fix It, at 15 (March 29, 2021), available at https://faculty.haas.berkeley.edu/shapiro/fixingantitrust.pdf; Jonathan Baker, THE ANTITRUST PARADIGM 168, 208 (2019). Andrew I. Gavil and Steven C. Salop, Probability, Presumptions and Evidentiary Burdens in Antitrust Analysis: Revitalizing the Rule of Reason for Exclusionary Conduct, 168 UNIV. PA. L.R. 2107 (2020).

${ }^{29}$ S. 225, 117th Cong., 11-12 (2021).

${ }^{30}$ See Gavil and Salop, supra note 28, for discussion of decision theory, judicial presumptions, and evidence.

${ }^{31} I d$.
} 
player. In the case of acquisitions by a dominant platform, the alternative acquirer is likely to be a firm that raises fewer if any competitive concerns. ${ }^{32}$ If there are no other bidders on the scene, it will be relevant whether there was no interest by others or whether the entrant skewed the process to favor the dominant firm.

38. This means that any efficiencies from expanding the scope of the entrant likely will be achieved even if the acquisition by the dominant firm is not permitted. It is possible that the dominant firm would achieve greater efficiencies. But in that case, only the incremental efficiencies would count as merger specific.

39. Second, the fact that there are commonly other potential acquirers for the acquired firm (either on the scene at the time or likely to enter the fray), the legal standard should place a greater weight on avoiding false negatives than avoiding false positive. Any efficiencies from the nascent competitor likely could be obtained from any number of purchasers. By contrast, the harms would come only from the acquisition by the dominant firm.

40. Third, if the potential entrant is unique or one of a few likely potential entrants, then the harm will be longer-term; the market will not self-correct. As emphasized by Bryan and Hovenkamp in their decision theory (error cost) analysis, market self-correction cannot occur if the entrants are acquired by the dominant firm. ${ }^{33}$ Self-correction is even less likely if an acquisition by the dominant firm dries up investment by other potential competitors, as found by Kamepalli, Rajan, and Zingales with respect to Facebook and Google acquisitions. ${ }^{34}$

41. Fourth, the fact that there typically are other potential acquirers that would compete against the dominant firm also is important for another reason. It sometimes is suggested that acquisitions of nascent competitors should not be constrained because acquisition is a common exit strategy for innovators, particularly those that lack the resources to grow on their own. ${ }^{35}$ However, since those nascent competitors normally have alternative acquirers that raise lesser competitive concerns than others, the viable exit strategy is maintained for

\footnotetext{
${ }^{32}$ In the rebuttal phase, the relative competitive impacts of the other potential bidders can be compared.

${ }^{33}$ See Kevin A. Bryan \& Erik Hovenkamp, Startup Acquisitions, Error Costs, and Antitrust Policy. 87 U. CHI. L. REV. 331 (2020), for a very similar decision theory analysis.

${ }^{34}$ Sai Kamepalli, Raghuram G. Rajan and Luigi Zingales, Kill Zone, University of Chicago, Becker Friedman Institute for Economics Working Paper No. 2020-19 (Feb. 15, 2021), available at https://ssrn.com/abstract $=3555915$.

${ }^{35}$ The literature on entry-for-buyout strategies generally assumes that there are not well-situated alternative purchasers that would compete against the dominant firm or underplays their existence. To the extent that the dominant firm is willing to pay more, that may be the result of it attempting to preserve its monopoly power. See, e.g., Eric Rasmussen, Entry for buyout, 36 J. Ind. Econ. 281 (1988); Luis Cabral Merger Policy in Digital Industries (2020), available at https://papers.ssrn.com/sol3/papers.cfm?abstract id=3612854; D. Daniel Sokol, Vertical Mergers and Entrepreneurial Exit, 70 FLA. L. REV. 1357 (2018); Michael L. Katz, Big-Tech Mergers: Innovation, Competition for the Market, and the Acquisition Of Emerging Competitors (2020), available at https://papers.ssrn.com/sol3/papers.cfm?abstract id=3624380; Steven Callander and Niko Matouschek, The Novelty of Innovation: Competition, Disruption, and Antitrust Policy (2020), available at https://sjc.people.stanford.edu/sites/g/files/sbiybj4051/f/innovation_13october2020.pdf.
} 
the entrant. ${ }^{36}$ Thus, preventing acquisitions by the dominant firm will eliminate the entryfor-buyout strategy.

42. Fifth, it might be argued that the dominant firm would pay more for the entrant, which signals that it would lead to greater consumer welfare. However, it is important not to fall into the trap of associating the relative proposed acquisition prices of various bidders with the relative values that consumers likely would receive. A higher bid by the dominant firm could well reflect a market power premium, that is, the value of the dominant firm of using the acquisition to maintain its market power by keeping the potential entrant out of the hands of other bidders that would use the acquisition to increase competition.

43. This market dynamic is simply another implication of the fact that monopoly profits exceed duopoly profits. It is straightforward to explain. ${ }^{37}$ Consider a dominant platform with substantial market power that is considering acquiring a nascent competitor. Suppose it is engaged in a bidding competition against a smaller rival or a firm currently selling in a different market but wants to acquire the nascent competitor to enter the market of the dominant platform or compete more intensely. The dominant platform has the incentive to bid more for the nascent competitor because it is paying to protect its supra-competitive profits rather than simply earn competitive profits. In this type of bidding competition, the dominant platform's bid would reflect its ability to maintain its highly supra-competitive ("monopoly") level of profits, rather than have its profits reduced to lower, more competitive level. By contrast, the bids of the rivals would reflect their ability to achieve only a more competitive profits level. It would be unlikely to replace the dominant platform, but only compete with it in a market that will become more competitive. Stated differently, those higher supra-competitive profits of the dominant platform will provide a "market power fund" to support higher bids by the dominant platform. For this reason, the amount that the dominant platform would be willing to pay to acquire the nascent competitor to protect its substantial market power would generally exceed the amount that the smaller rival would be willing to pay.

44. This analysis can be illustrated with a simple numerical example. Suppose that a dominant platform has supra-competitive profits of 200 that they would be maintained if it wins the auction for the nascent or potential competitor. By contrast, suppose that if a smaller competitor instead wins the bidding, the dominant platform's profits would fall to 100 . Suppose that the smaller competitor's profits would rise from 20 up to 60, that is, general incremental profits of 40 . In this situation, the smaller competitor would only be willing to bid up to 40 , which represents its incremental profits from winning the bid. However, the dominant platform would be willing to bid up to 100 (i.e., 200 less 100), which represents its

\footnotetext{
${ }^{36}$ Hemphill and Wu, supra note 7; John M. Newman, Expanding the Merger Narrative: A Response to Sokol, 70 FLA. L. REV. F. 179, 184 (2020).

${ }^{37}$ Gilbert and Newberry, supra note 3.
} 
incremental profits from winning the bid and maintaining its high supra-competitive profits. In a second price auction, for example, the dominant platform could win the bidding with a price of 41. This is far below its incremental profits of 100. Thus, the nascent competitor would obtain an acquisition price of 41 and the dominant platform would retain the other 69 (i.e., 100-41) in net pecuniary benefits. This bidding situation is pictured in Table 1 below.

45. Thus, the dominant platform exhibits a greater willingness to pay because its stakes in the bidding are higher than the smaller platform's stakes. This is because the dominant platform's incremental value from maintaining substantial market power (here, 100) exceeds the competitor's incremental value from earning slightly higher competitive profits (here, 40). This divergence in profits is the typical result because total industry profits when there is substantial market power (here, $200+20=220$ ) generally exceed total industry profits when there is competition (here, $100+60=160$ ). This divergence results from the fact that competition tends to benefit consumers by reducing total industry profits.

Table 1: The Inherent Bidding Advantage of a Dominant Firm

\begin{tabular}{|c|c|c|c|c|}
\hline & \multicolumn{2}{|c|}{ Profit by Winning Bidder } & \multirow[b]{2}{*}{$\begin{array}{c}\text { Maximum } \\
\text { Bid }\end{array}$} \\
\hline & & $\begin{array}{c}\text { Dominant } \\
\text { Platform } \\
\text { Wins }\end{array}$ & $\begin{array}{l}\text { Rival } \\
\text { Wins }\end{array}$ & \\
\hline \multirow{2}{*}{ : } & $\begin{array}{l}\text { Dominant } \\
\text { Platform }\end{array}$ & 200 & 100 & $\begin{array}{c}100 \\
\text { (i.e., } 200-100)\end{array}$ \\
\hline & Rival Bidder & 20 & 60 & 40 \\
\hline & $\begin{array}{l}\text { Combined } \\
\text { Profits }\end{array}$ & 220 & 160 & \\
\hline
\end{tabular}

46. Sixth, the rebuttal burden should be higher because the acquisition generally is not the dominant firm's only route to obtaining the hoped-for alleged efficiency benefits of the merger. The dominant firm may be able to achieve the benefits with its own investment. Moreover, this alternative route does not simply apply to acquisitions of nascent direct competitors, but also to the acquisition of complementary or vertically adjacent nascent or potential competitors. If the acquisition target has a key product feature, the acquiring firm generally would create its own version absent the merger. ${ }^{38}$ The only merger-specific

\footnotetext{
${ }^{38}$ For example, Congressional hearings on Big Tech revealed how Facebook both copies and acquires rival technologies to maintain the dominance of its social media platform. Online Platforms and Market Power (part 6): examining the Dominance of Amazon, Apple, Facebook, and Google: Hearing Before the Subcomm. on Antitrust, Commercial, and Administrative Law, 116 Cong. (2020) at 2:42:43. A transcript is available at Big Tech Antitrust
} 
efficiency then might be the dominant firm more quickly rolling out the feature, not the product improvement generally. ${ }^{39}$ Of course, this is a much smaller efficiency benefit. It also leaves out the fact that the nascent competitor might have rolled out the feature with an alternative partner, or that the dominant firm could have licensed the feature instead. Thus, any ncremental benefits from reduced delay are less likely to reverse the merger's potential anticompetitive effects.

47. The analysis contained in these points leads to the conclusion that there should be an intrusive legal standard: when the dominant firm (or leading firm in a highly concentrated market) proposes to acquire a unique potential entrant (or one of only a small number), the law should apply a strong anticompetitive presumption with a high rebuttal burden placed on the acquiring firm. This recommended legal standard is in marked contrast to the current, permissive legal standard applied in the U.S.

\section{Anticompetitive Conduct to Exclude Nascent or Potential Competitors}

48. In this section, I examine several issues related to anticompetitive exclusionary conduct that targets nascent or potential competitors.

\section{A. Basic Economic Analysis}

49. A common antitrust allegation involves exclusionary conduct by a dominant firm to raise the costs or otherwise destroy a nascent competitor or potential entrant. If the potential competitor's costs are raised to the point that it cannot compete at the monopoly price, then entry would be deterred, even if the entrant lacks any sunk or fixed costs. ${ }^{40}$ If the competitor's cost are increased to a level less than the monopoly price, the dominant firm gains by facing less of a pricing constraint.

50. Figure 3 illustrates this point. The diagram pictures a potential entrant with a cost disadvantage $\mathrm{C}_{\mathrm{E}}>\mathrm{Cm}$, but its variable costs $\mathrm{C}_{\mathrm{E}}$ are either above the monopoly price (i.e., $\left.\mathrm{C}_{\mathrm{EH}}>\mathrm{Pm}\right)$ or less than the monopoly price $\left(\mathrm{C}_{\mathrm{EL}}<\mathrm{Pm}\right)$. In the former case, the monopolist remains unconstrained. In the latter case, the monopolist cannot ignore the potential of entry. If it faces a threat of entry from this latter entrant, its price increases are limited to a price

Hearing Full Transcript, REv, (Jul. 29, 2020), https://www.rev.com/blog/transcripts/big-tech-antitrust-hearing-fulltranscript-july-29.

${ }^{39}$ The U.S. Horizontal Merger Guidelines place less weight on the benefits of reducing delay. See US HMGs, supra note 4 at n. 15 .

${ }^{40}$ As discussed in Section II, where the potential entrant has sunk and fixed costs, the fear of post-entry competition will be a greater concern because the entrant will have a higher minimum viable scale and greater profit exposure from its sunk costs if its entry fails. 
level (slightly) below the entrant's variable costs. This price is called the "Limit Price." Only if $\mathrm{C}_{\mathrm{E}}=\mathrm{Cm}$ is the monopolist (or merged firm) unable to raise price.

Figure 3: Raising Entrant's Costs

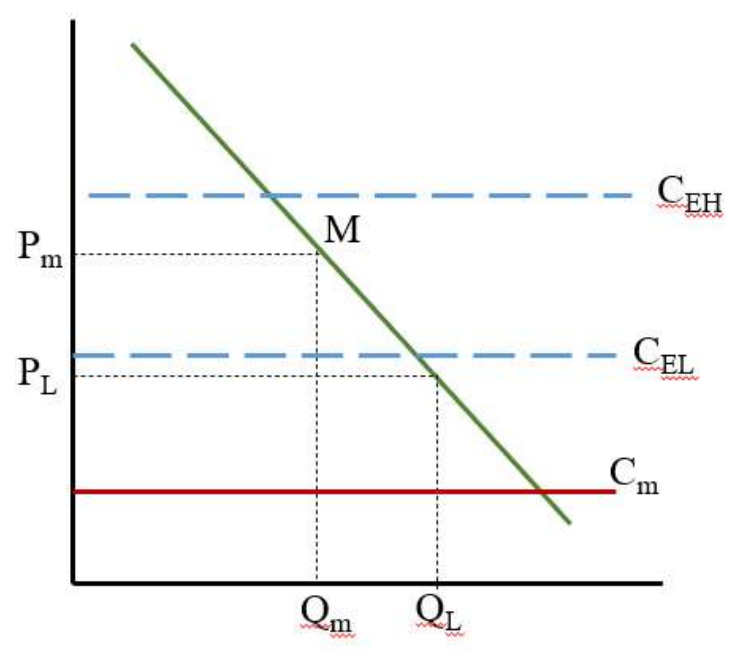

51. There are numerous U.S. antitrust cases that fit this paradigm. AT\&T engaged in various actions to raise the costs of MCI and other nascent long distance telephone competitors in the 1970s, conduct that led to the break-up of AT\&T in $1982 .{ }^{41}$ Microsoft's panoply of exclusionary conduct towards Netscape eliminated the middleware threat and maintained the applications barrier to entry that protected Microsoft's desktop operating system monopoly. ${ }^{42}$ A group of real estate brokers in the state of Michigan were found liable for raising the costs and reducing the scope of nascent discount brokers who were charging lower commissions on the sale of houses. ${ }^{43}$ Verizon destroyed competition for providing DSL internet access by a competitive carrier by refusing to sell it unbundled access to the essential input under the regulated terms set out by Federal Communications Commission. ${ }^{44}$ In the McWane case, the dominant seller of pipe fittings used exclusive dealing with distributors to raise the costs and constrain the output of Star and Sigma, two new entrants. ${ }^{45}$

\footnotetext{
${ }^{41}$ United States v. American Tel. \& Tel. Co., 552 F. Supp. 131 (D.D.C. 1982) (approving a consent decree between the Department of Justice and AT\&T resulting in AT\&T's breakup.).

42 United States v. Microsoft Corporation, 253 F.3d 34 (D.C. Cir. 2001).

${ }^{43}$ Realcomp II, Ltd. v. FTC, 635 F.3d 815 (6th Cir. 2011).

${ }^{44}$ Verizon Commc'ns, Inc. v. Law Offices of Curtis V. Trinko, LLP, 540 U.S. 398 (2004). However, the U.S. Supreme Court held that while this exclusionary may have violated certain regulations, this type of unconditional refusal to deal did not violate the U.S. antitrust laws.

${ }^{45}$ McWane, Inc. v. FTC, 783 F.3d 814 (11th Cir. 2015).
} 
52. When a dominant firm engages in conduct to exclude a new entrant, the conduct does not strictly raise prices. Instead, it allows the dominant firm to maintain its supra-competitive price and prevent from falling. In the language of the U.S. antitrust laws, the conduct is designed to maintain monopoly power, not achieve it. Thus, the court should not look to evidence that price increased. Instead, it is more relevant that price failed to decrease in response to entry. These procompetitive price decreases can be deterred by raising the costs of the entrant or causing it exit from the market.

53. Procompetitive price decreases also can be deterred by exclusionary conduct that prevents the entrant from growing. This is because the dominant firm might find it profitable simply to accommodate small scale entry without having the need to reduce its own price. ${ }^{46}$ However, the fact that the entry succeeds nonetheless is consistent with the exclusionary conduct being anticompetitive. For example, suppose that the entrant offers a price that is $10 \%$ below the monopolist's but the monopolist's exclusionary conduct would prevent the entrant from achieving a market share of more than 5\%. In this situation, it may be more profitable for the monopolist to cede the $5 \%$ market share loss rather than reduce its price by (say) $15 \%$ to recapture the sales. ${ }^{47}$ This incentive to accommodate the entry would be even stronger if the entrant would only exit if prices fell by $25 \%$ instead of only $10 \%$.

\section{B. The Competitive Benefits of Even Less-Efficient Competitors}

54. An equally efficient competitor (EEC) standard should not apply to exclusionary conduct towards nascent or potential competitors. Application of that standard would provide dominant firms with substantial discretion to exclude competition.

55. Conduct that would be unable to exclude an entrant that was as efficient as the dominant firm nonetheless could destroy a less efficient nascent competitor or deter a potential entrant. For example, suppose that conduct of the dominant firm raises the marginal costs of the nascent competitor by some amount. If the competitor is less efficient, its resulting costs may exceed the dominant firm's current (monopoly level) price. By contrast, if the firm were as-efficient, its marginal costs might remain below the dominant firm's price. This is illustrated in Figure 4, where the dominant firm's price is $\mathrm{P}_{\mathrm{m}}$, the marginal costs of the as-efficient entrant are $\mathrm{C}_{\mathrm{AE}}$ and the marginal costs of the less-efficient entrant are $\mathrm{C}_{\mathrm{LE}}$.

\footnotetext{
${ }^{46}$ This scenario roughly fits the facts of McWane.

${ }^{47}$ See Judith R. Gelman and Steven C. Salop, Judo Economics: Capacity Limitation and Coupon Competition, 14 BELL J. ECON. 315 (1983).
} 


\section{Figure 4: Excluding a Less Efficient Entrant}

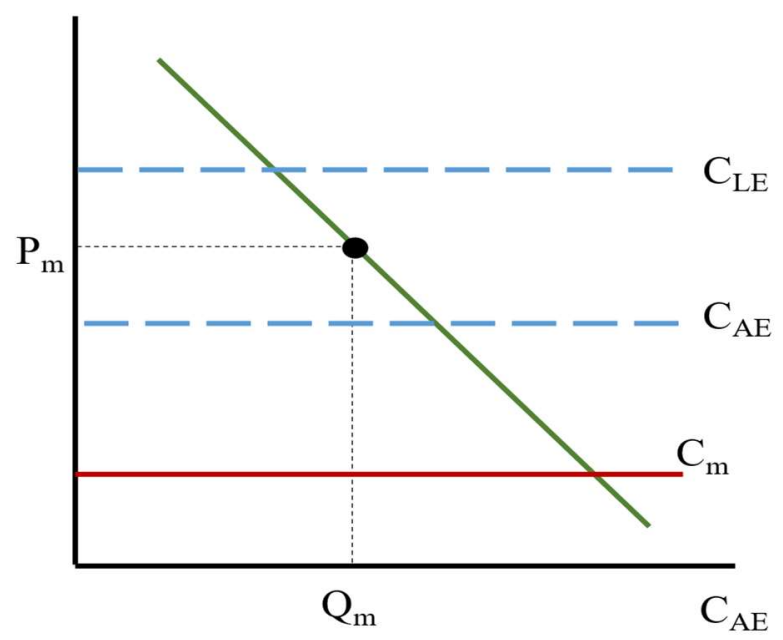

56. Any competition policy that allows dominant firms to exclude less efficient entrants would be insufficient for two reasons. First, even if the entrant has higher costs than the dominant firm, its entry nonetheless will benefit competition and consumers. This is because the entry often will cause the dominant firm to reduce its own prices in response. In the simplest economic model, entry will cause such a procompetitive price response as long as the entrant's costs are less than the dominant firm's price. Even if the entry occurs on a small scale and leads the dominant firm to accommodate the entry without reducing its price, consumers will benefit from the lower prices of the entrant and the additional choice. Second, and related, the inefficient entrant may become an equally or more efficient competitor as it gains experience in the industry or invests after achieving viability.

57. This same analysis applies to the use of the EEC standard for foreclosure conduct targeted against an established firm. In fact, the EEC "standard" has always been something of misnomer. An often-used evidentiary prong for predatory pricing involves evaluating whether the defendant is pricing below its costs. This has been described as an EEC standard because such a price also would be below the cost of an equally efficient competitor. However, this is really more of a way to describe the price-cost test rather than being a true legal standard. If the excluded entrant in fact had higher costs, evidence that the dominant firm priced below its own costs would still fail the test. That is, EEC test is better described here as "whether the defendant set a price that would be capable of excluding an equally efficient competitor?" And even explained in this way, the test is defective - at least outside of plain vanilla predatory pricing -- for the reasons set out above. ${ }^{48}$

\footnotetext{
${ }^{48}$ I refer here to "plain vanilla" predatory pricing because the incremental price-cost test might erroneously be applied to conditional pricing practices (i.e., loyalty discounts and bundled discounts). See also Steven C. Salop, The
} 
58. In addition, there is a question of how to define "equally efficient" when the products are differentiated. For example, suppose that the dominant and entrant have identical fixed and marginal costs. Suppose that their products are differentiated, so that some consumers would prefer each of them if their prices were identical. If their market shares would each be 50 percent at identical prices, then they clearly would be equally efficient. However, suppose instead that the monopolist would obtain 80 percent of the customers at identical prices. This could be said to suggest that the monopolist's product is "better" as far as most consumers are concerned, so that the entrant could be characterized as less efficient. But, even if a high fraction of consumers does prefer the monopolist's product, a significant number prefer the entrant's product. Thus, if the entrant were forced to exit as a result of exclusionary conduct, some consumers would clearly be harmed, and that harm would need to figure in the welfare balance. This is an important point because it is common for entrants to sell differentiated products.

\section{Avoiding the Cellophane Fallacy}

59. In analyzing cases involving such monopoly maintenance, it is important that courts and regulators do not fall victim to the famous Cellophane Fallacy. ${ }^{49}$ The fallacy is the following. In a case alleging that a firm has engaged in exclusionary conduct to destroy and entrant and maintain dominance, the defendant argues that the allegations fail because it lacks monopoly power. The firm cites as proof for its lack of monopoly power evidence that it would not be profitable for the firm to raise its price above the prevailing price. ${ }^{50}$

60. Stated in this way, the fallacy is obvious. The antitrust allegation is that the firm has engaged in conduct to prevent prices from falling, not raising price above the current level. The fact that it would be unprofitable to raise price is irrelevant to the issue of whether the entry would have caused prices to fall.

61. Of course, the fallacy is even deeper. The fact that a firm would not find it profitable to raise above the prevailing price does not prove lack of monopoly power. If a firm is charging the monopoly price, it lacks an incentive to raise price above that level. The monopoly price already is the profit-maximizing price. Indeed, any rational firm unilaterally sets its price at

Raising Rivals' Cost Foreclosure Paradigm, Conditional Pricing Practices, and the Flawed Incremental Price-Cost Test, 81 ANTITRUST L.J. 371 (2017).

49 The U.S. Supreme Court fell victim to the fallacy in finding that duPont did not monopolize an alleged market for cellophane because price increase above the prevailing level would not have been profitable. United States v. E.I. du Pont de Nemours \& Co., 351 U.S. 377 (1956). That Court failed to account for the fact that the allegedly monopolizing conduct in the past is what allowed du Pont to raise the price of cellophane up to the prevailing level. This is sometimes referred to as the Cellophane Trap rather than Fallacy. See, e.g., David Glasner \& Sean P. Sullivan, The Logic of Market Definition, 83 ANTITRUST L. J. 293 (2020).

${ }^{50}$ See George W. Stocking, Economic Tests of Monopoly and the Concept of the Relevant Market. 2 ANTITRUST Bull. 479 (1957), for one of the first of many analyses of the fallacy. See Steven C. Salop's The First Principles Approach to Antitrust, Kodak, and Antitrust at the Millennium. 68 ANTITRUST L.J. 187 (2000), for discussion of several variants on the basic fallacy. 
the profit-maximizing level, which means that a price increase above that level would not increase its profits.

62. The fallacy can be avoided if the enforcement agent realizes that any use of the standard hypothetical monopolist test (HMT) must not use the prevailing (monopoly) price as the benchmark price for the price increase (SSNIP). If the HMT test is to be applied, the benchmark price must be a lower, competitive price. Even better, rather than trying to evaluate market power separately from competitive effects, it makes more sense to evaluate the likely impact of the alleged exclusionary conduct on prices. If the conduct would prevent prices from falling, whereas prices would fall absent the conduct, then one can conclude directly that the conduct is anticompetitive. This finding also implies that the defendant has market power in a narrowly defined market. ${ }^{51}$

63. In his dissenting opinion in the American Express case, Justice Breyer succinctly summarized this approach as follows:

$[\mathrm{P}]$ roof of actual adverse effects on competition is, a fortiori, proof of market power. Without such power, the restraints could not have brought about the anticompetitive effects that the plaintiff proved. *** The District Court's findings of actual anticompetitive harm from the nondiscrimination provisions thus showed that, whatever the relevant market might be, American Express had enough power in that market to cause that harm. There is no reason to require a separate showing of market definition and market power under such circumstances. And so the majority's extensive discussion of market definition is legally unnecessary. $^{52}$

\section{Competitive Bidding for Critical Distribution Services or Other Essential Inputs}

64. One way that dominant firms can deter competition and preserve their monopoly power is by gaining exclusive control over critical distribution services or other critical inputs that nascent competitors need to maintain viability and growth in the market. However, some conservative commentators and U.S. courts suggest that entrants and nascent competitors can protect themselves (and consumer interests) competitive bidding for the distribution services and other inputs. For example, if the dominant firm offers to pay critical distributors for exclusivity, the entrant can counterbid for non-exclusive access. In this way, attempted exclusion by the

\footnotetext{
51 See Salop, supra note 50, for further details of this approach.

${ }^{52}$ Ohio v. Am. Express Co., 138 S. Ct. 2274 (2018) (Breyer, J., dissenting).
} 
dominant firm will become more expensive and supposedly often will fail as a result.

65. However, this general claim is fundamentally flawed. ${ }^{53}$ While successful exclusion is not inevitable, it can succeed in a wide variety of circumstances.

66. First, bidding competition may not even occur. The dominant firm may tie up inputs or distributors with long term contracts in anticipation of entry before the entrant arrives on the scene to counterbid.

67. Second, the claim that entrants can outbid the dominant firm overlooks the fact that monopoly profits generally exceed duopoly profits. ${ }^{54}$ Thus, the dominant firm will have the systematic incentive to outbid the entrant. The cost of the exclusionary strategy will rise. But the differential between monopoly and duopoly profits will provide the dominant firm with a large cushion to ensure that the exclusion will remain successful.

68. This bidding competition can be illustrated with Table 1, where the payoffs now can be interpreted as the profits of the dominant firm and a nascent competitor, according to which one wins the bidding. If the dominant firm prevails and obtains an exclusive, it will earn profits of 200 and the nascent competitor will earn 20. If the nascent competitor instead obtains a non-exclusive, the dominant firm will earn 100 and the nascent competitor will earn 60 instead of 20. Thus, the nascent competitor would be willing to bid up to 40 for access to the distributor, whereas the dominant firm would be willing to bid up to 100 to deny that access. As a result, the dominant firm will obtain the exclusive for a price of 41 and still achieve net profits (over and above the cost of the exclusive) of 159 (i.e., 200-41). The fact that the dominant firm can win the bidding for a price below its profits also illustrates the fact that the dominant firm does not have to offer a lossproducing compensation to the distributor. ${ }^{55}$

69. Analysis of this bidding competition is more complicated when there are multiple distributors. Depending on the specifics, it is possible that the nascent competitor will not even have an incentive to try to outbid the dominant firm. For other

\footnotetext{
53 See Salop, supra note 48, for further analysis of this type of bidding competition.

${ }^{54}$ As noted earlier, monopoly profits are not always higher. The entrant may have much lower costs or a better or highly differentiated product. But it is the more usual case.

55 Table 1 assumes that the distributor is indifferent to the identity of the auction winner. It is possible that the distributor would prefer to have the non-exclusive contract, in which case the dominant firm would need to pay more. However, so long as monopoly profits to all three firms exceed competitive profits, which is normally the case, the dominant firm wil prevail.
} 
situations, the nascent competitor will prevail, and the dominant firm may not even try to exclude.

70. To illustrate this analysis, assume the payoffs for monopoly versus entry in Table 1. But assume instead that there are three potential distributors, and the nascent competitor must obtain non-exclusives from two of them in order to be viable. Suppose that nascent competitor happens to win the bidding for one distributor. In that case, the dominant firm still would have the incentive to pay 41 to each of the other two distributors (a total of 82) rather than have the nascent competitor become viable, in which case the dominant firm's profits will fall by 100 . Of course, anticipating this outcome, a rational nascent competitor would be foolish to pay the first distributor for a non-exclusive, knowing that this cost will he wasted when it fails to obtain non-exclusive distribution from another distributor.

71. By contrast, suppose instead that the nascent competitor only needed to obtain non-exclusive distribution from a single distributor in order to achieve viability. In this case, the dominant firm would not find it profitable to exclude the nascent competitor. To do so, the dominant firm would need to outbid the nascent competitor at all three distributors at a total cost of 123 (i.e., $3 \times 41$ ), which exceeds the reduction in its profits from the successful entry. Thus, unless the dominant firm gains some advantage (outside this narrow model) from forcing the nascent competitor to pay for the non-exclusive, the dominant firm would lack the incentive to enter the bidding competition.

72. By contrast, if the nascent competitor has sufficient advantages that lead to duopoly profits exceeding monopoly profits, then competition for distribution or other inputs will lead to competition in many situations.

73. Third, if the nascent competitor needs multiple distributors, it may face a severe coordination problem. Individual distributors may prefer the nascent competitor to succeed, but fears being punished by the dominant firm if the nascent competitor fails. This creates the potential for a self-fulfilling monopoly equilibrium. ${ }^{56}$

\section{E. The Appropriate Legal Standard}

74. The legal standard for liability in private exclusion cases brought by an excluded nascent competitor or entrant should not place an excessively high bar on the plaintiff. When the defendant is a dominant firm, its financial stakes are much higher than the stakes of the plaintiff. Whereas the defendant is hoping to win the case in order to avoid competition and continue to earn monopoly profits, the

${ }^{56}$ See also Eric B. Rasmusen, J. Mark Ramseyer, John S. Wiley, Jr., Naked Exclusion, 81 AM. ECON. REV.1137 (1991); Salop, supra note 48. 
plaintiff is hoping to win the case in order to compete and earn more competitive (e.g., duopoly) profits. The higher stakes of the defendant will incentivize it to invest more money in the litigation, relative to the plaintiff. Since the court will decide based on the evidence presented, the outcome of such cases will be skewed away from the purely merits-based outcome in the defendant's favor. ${ }^{57}$

75. Considering these asymmetric stakes, it is appropriate to adjust the legal standard to compensate for the skewed outcomes. This can be implemented by reducing the plaintiff's burden of proof to something lower than "more likely than not" (or, "preponderance of the evidence") to cause anticompetitive effects. Alternatively, the legal standard might involve placing a lower burden on the plaintiff's prima facie case and a higher rebuttal burden on the defendant. ${ }^{58}$

\section{EXCLUSIONARY AgREements BeTWEen INCUMBENTS AND PoTENTIAL OR NASCENT COMPETITORS}

76. The previous section explained that mergers between dominant incumbents and potential or nascent competitors that raise inherent anticompetitive concerns. The same concerns arise from exclusionary agreements to weaken or destroy entry. Those agreement can reduce or eliminate the competitive impact of the nascent or potential competitor and thereby allow the dominant firm to continue to exercise monopoly power and earn monopoly profits. The fact that monopoly profits exceed the combined duopoly profits provide a mutual incentive to make such exclusionary agreements.

\section{A. Examples of Anticompetitive Agreements}

77. This issue has been analyzed in detail in the context of agreements between branded pharmaceutical products and generic entrants. In U.S. cases such as Actavis, ${ }^{59}$ the branded pharmaceutical producer institutes a patent infringement case against the entrant and then the parties settle the case with a provision that the entrant delays its entry, along with a so-called "reverse" payment to the potential entrant. It has been recognized that these "pay for delay" settlements can permit the incumbent to delay the onset of competition. The payment to the potential entrant is a way to share the resulting continuation of monopoly profits.

78. These same concerns apply to other industries and situations that do not involve patents and do not share the same regulatory structure as pharmaceuticals. As a general matter, "backward" entry by large customers into the production of an input and competition in

\footnotetext{
${ }^{57}$ See Erik Hovenkamp and Steven C. Salop, Strategic Incentives in Non-Coasian Litigation (Apr. 6, 2021), available at https://papers.ssrn.com/sol3/papers.cfm?abstract_id=3821133.

${ }^{58} I d$.

${ }^{59}$ FTC v. Actavis, Inc., 570 U.S. 136 (2013).
} 
selling the input to others may be deterred by offering the customer a favorable price for the input being provided. ${ }^{60}$ The Google search case now being litigated in the U.S. provides an excellent example. In the U.S., the Apple iPhone is a very popular. ${ }^{61}$ It is reported in the U.S. complaint that almost $50 \%$ of Google search traffic originated on Apple devices in 2019. ${ }^{62}$ The complaint also alleged that the Google-Apple agreements covered approximately $36 \%$ of US search queries in $2019 .{ }^{63}$ These figures suggest that Apple was a potential entrant into search or a potential entrant sponsor. Such entry could lead to competition for advertising sales that would significantly reduce Google's profits. Thus, it is perhaps not surprising that Google would have been willing to pay Apple \$8-12 billion annually to eliminate this competitive threat by paying Apple for Google search being the default on Apple devices. ${ }^{64}$

79. A similar allegation has been made against Google in the antitrust case brought by a group of U.S. State Attorneys' General. They allege and Google and Facebook made an agreement that reduced the threat of "Header Bidding" competition and Facebook providing advertising network competition. ${ }^{65}$ exchanges. While it is difficult for an outsider to discover such agreements, there may be others.

80. It is also important to recognize that entry may be deterred or competition reduced by crossownership between the dominant firm and the nascent or potential competitor. ${ }^{66}$ For example, Tencent and Spotify have approximately $8-9 \%$ ownership interests in one another. ${ }^{67}$

\footnotetext{
${ }^{60}$ For an early recognition and analysis of this issue, See David Scheffman and Pablo T. Spiller, Buyers' Strategies,
} Entry Barriers, and Competition. 30 ECONOMIC INQUIRY 418 (1992).

${ }^{61}$ Almost half of smartphone users currently use an iPhone. See Share of smartphone users that use an Apple iPhone in the United States from 2014 to 2021, STATISTA (Mar. 31, 2021), available at www.statista.com/statistics/236550/percentage-of-us-population-that-own-a-iphone-smartphone/. The earlier parallel EU case focused on the Android licensees rather than Apple, in that the iPhone is much smaller in Europe. Case AT-40099, Google Android, 2019 J.O. (C 402) 1, 38-56.

${ }^{62}$ Complaint at $28 \uparrow 121$, United States v. Google, (D.D.C. Oct. 10, 2020) (No. 1:20-cv-03010),

${ }^{63} I d$.

64 Tim Higgins, Apple's Booming Services Business Could Be Hit in Google Antitrust Battle, THE WALL STREET JOURNAL (Oct. 25, 2020), available at www.wsj.com/articles/apples-booming-services-business-could-be-hit-ingoogle-antitrust-battle-11603659010.

${ }^{65}$ Compl., Texas v. Google, LLC, (E.D. Tex. Dec. 16, 2020) (No. 4:20-cv-00957), available at https://www.texasattorneygeneral.gov/sites/default/files/images/admin/2020/Press/20201216\%20COMPLAINT_RE DACTED.pdf.

\footnotetext{
${ }^{66}$ See Daniel P. O’Brien and Steven C. Salop, Competitive Effects of Partial Ownership: Financial Interest and Corporate Control, 67 Antitrust L.J. 559 (2000), available at https://scholarship.law.georgetown.edu/cgi/viewcontent.cgi?article=1200\&context=facpub, for analysis of the impact of partial ownership on competitive incentives. See also US HMGs, supra note 4 at $\S 13$.

${ }^{67}$ See, e.g., Jon Russell Spotify and Tencent Agree to Swap Stakes in Their Music Businesses, TECHCRUNCH (Dec. 8 , 2017), available at https://techcrunch.com/2017/12/08/spotify-tencent-share-swap/;
} 
While Tencent is the dominant streaming music platform in China, it has not entered countries where Spotify competes and Spotify does not compete in China.

\section{B. Litigation Settlements}

81. As suggested by Actavis, litigation settlements in exclusion cases can serve as anticompetitive agreements. When the defendant is a dominant firm with substantial market power, the parties have a substantial mutual incentive to settle the case in a manner that permits the dominant firm to continue to exercise monopoly power and earn the monopoly profits. This is because the monopoly profits exceed the combined duopoly profits of the two litigants. The settlement is a way to share the incremental profits from monopoly rather than competition.

82. This mutual economic incentive can be illustrated by reinterpreting the profit matrix in Table 1 to apply to the possible outcomes of the litigation. Assume that if the defendant (i.e., the dominant firm) wins the litigation, it will be able to continue to earn the monopoly profits of 200. By contrast, if the smaller plaintiff wins, it will earn incremental profits of 40 while the defendant's profits fall to 100 , for combined profits of 140 . Under these circumstances, a settlement that permits the dominant firm to continue to exercise monopoly power while the smaller firm exits increases the litigants' combined profits by 60 (i.e., 220-160). The settlement can divide these profits in proportion to the plaintiff's probability of winning and the litigants' relative bargaining skill.

83. This analysis has two important policy implications. First, it suggests that courts and regulatory agencies should not routinely approve such settlements. They should recognize that settlements in exclusionary conduct cases can be anticompetitive. The authorities should require that settlements be structured solely to enjoin the anticompetitive conduct and thereby ensure that there will be additional post-settlement competition. ${ }^{68}$ Where the plaintiff's probability of winning is less than unity, an acceptable injunction would eliminate some but not all of the anticompetitive conduct and thereby to reduce the defendant's market power by a corresponding fraction. ${ }^{69}$ What is problematical are settlements that permit the continued

https://techcrunch.com/2018/02/28/tencent-music-spotify/. The 21\% refers to the fraction of Class A shares, not total shares.

${ }^{68}$ For example, if the dominant firm is accused of exclusive dealing, the partial injunction would eliminate some but not all the exclusives and thereby partially reduce the market power. See Hovenkamp and Salop, supra note 57, for further details.

${ }^{69}$ Erik Hovenkamp. Antitrust Law and Patent Settlement Design, 32 HARV. J.L. \& TECH 417 (2019); Erik Hovenkamp and Jorge Lemus. Antitrust Limits on Patent Settlements: A New Approach, J. INDUS. ECON. (forthcoming, 2021). 
exercise of the monopoly power, while providing the plaintiff with a cash (or equivalent) payment in exchange for reducing its competitive threat. ${ }^{70}$

\section{CONCLUSIONS}

84. As discussed in the Introduction, it is important for competition policy to maintain effective competition by protecting nascent and potential competitors. These competitors often are the leading edge of competition to undermine the monopoly power of the dominant firms. And because monopoly profits exceed duopoly profits, the deck is stacked against these competitors. The dominant firm's incentive to spend is greater than the entrant's because the dominant firm is spending to protect its monopoly profits while the entrant is spending to achieve the lesser, competitive duopoly profits.

85. The importance of nascent and potential competition and the asymmetry of the stakes involved suggests that competition law should place an anticompetitive presumption on alleged exclusionary conduct and acquisitions by dominant firms. Enforcement agencies also should closely monitor agreements, including litigation settlements between dominant firms and their smaller competitors, to determine whether they are serving to eliminate competition and preserve monopoly power.

\footnotetext{
${ }^{70}$ A practical complexity arises if the plaintiff demands damages for past anticompetitive conduct. The damages settlement payment could be used to disguise a cash payment for sharing the future monopoly profits from an insufficient conduct injunction. See Hovenkamp \& Salop, supra note 57.
} 